\title{
Compost and Wildflowers for the Management of Urban Derelict Soils
}

\author{
Roberto Pini, Francesca Bretzel, Enzo Sparvoli, Beatrice Pezzarossa, and Manuele Scatena
}

CNR, Istituto per lo Studio degli Ecosistemi, Via Moruzzi 1, 56124 Pisa, Italy

Correspondence should be addressed to Roberto Pini, roberto.pini@ise.cnr.it

Received 5 July 2011; Accepted 23 November 2011

Academic Editor: Horea Cacovean

Copyright () 2012 Roberto Pini et al. This is an open access article distributed under the Creative Commons Attribution License, which permits unrestricted use, distribution, and reproduction in any medium, provided the original work is properly cited.

The aim of this study was to verify whether the use of source-separated municipal waste compost could improve the physical quality of urban soils and create better conditions for their management when planted with herbaceous species. A sandy soil in traffic islands was tilled to a depth of $10 \mathrm{~cm}$, and half of the surface was treated with compost $\left(3 \mathrm{~kg} / \mathrm{m}^{2}\right)$. A mixture of 25 herbaceous annuals was then sown in the entire area. Organic carbon content and physical characteristics were determined at different times in the soil treated and not treated with compost. The vegetation was monitored in terms of its growth and flowering. The composttreated soil showed an increase in organic carbon content. Total porosity increased with time in the compost-treated soil, due to a higher volume of transmission pores, which play a role in water movement. Soil aggregate stability also improved in the compost-treated soil. The duration of flowering of the individual species and the overall quantity of flowers were greater in the compost-treated soil.

\section{Introduction}

Soil is one of the limiting factors for the successful cultivation of plants in towns and cities [1]. The poor quality of soils in urban areas is due to their chemical and biological properties but more often it is due to physical properties. Often urban soils are lacking in structure and humus, leading to asphyctic conditions, compaction, and erosion. These poor physical properties reduce the water available for plants and the penetrability of soils by the roots. Moreover, urban soils can be contaminated by several anthropogenic materials (bricks, concrete, and plastic), which can greatly reduce the volume available for plant roots. The use of source-separated municipal solid waste compost could provide a good solution for increasing the organic matter content in urban soils and for improving their physical properties. In Italy, the production of such compost is rapidly increasing due to the efforts of municipalities to achieve a better selection of organic solid waste and to improve composting processes. So using this compost in vast and heterogeneous sets of urban soils could also help to create a high-value market for locally produced compost, as pointed out by Cogger [2] . While compost effects on agricultural soils have been widely studied, less information is available on urban soils, though interest and research are increasing [3]. In particular one possible effective use of quality compost is in urban derelict soils. These kind of soils, found in roadsides, roundabouts, and filling soils, are generally highly compacted in subsoils, particularly poor in organic matter and structure, and are polluted by traffic [4]. Thus, they are often unsuitable for growing any ornamental vegetation. These soils could benefit from being treated with compost, thus improving their structure and water-holding capacity and making them suitable for growing some ornamental vegetation [5]. They are planted generally with grasses selected for rapid growth and effectiveness in terms of erosion control [6]. These species provide a monotonous landscape and require a great deal of water plus frequent cutting, which involve high costs in terms of maintenance. However, many herbaceous plants, native to the Mediterranean climate and which tolerate drought conditions, have the potential to be used for low-maintenance landscaping [7]. Over the last few decades, interest in using flowering plants (wildflowers) for landscape purposes has increased [8]. In fact, these plants enable derelict soils to vegetate, and when sown in mixture they enhance wildlife and look colorful and attractive. The 
TABLE 1: Compost characteristics and corresponding values requested by Italian law.

\begin{tabular}{lcc}
\hline & compost & Italian law \\
\hline Water content \% & 21.6 & $<50$ \\
$\mathrm{pH}$ & 7.15 & $6.0-8.5$ \\
Organic C\% & 30.1 & $>25$ \\
Total N\% & 1.68 & - \\
Organic N\% of tot N & 88.1 & - \\
C/N & 17.9 & $<25$ \\
\hline
\end{tabular}

establishment of a wildflower meadow leads to a reduction in management costs due to the absence of fertilization and irrigation and to the low level of other management practice [9].

The aim of this study was to see whether the use of source-separated municipal solid waste compost could improve the physical quality of an urban derelict soil and create better conditions for its management when planted with herbaceous species.

\section{Materials and Methods}

2.1. Study Site. The study was carried out during a growing season (November to June) in Livorno, a Tuscan town on the Mediterranean coast, where the maximum and the minimum temperature recorded in the experimental period were $33.0^{\circ} \mathrm{C}$ and $1.9^{\circ} \mathrm{C}$, the coldest month being February (mean temp. $12.4^{\circ} \mathrm{C}$ ) and the warmest month being June (mean temperature $22.6^{\circ} \mathrm{C}$ ), with an average relative humidity of $74.7 \%$ and a total precipitation of $367 \mathrm{~L} / \mathrm{m}^{2}$.

The field site was a group of three traffic islands of different shape measuring, respectively, $160 \mathrm{~m}^{2}$ (island A), $120 \mathrm{~m}^{2}$ (island B), and $280 \mathrm{~m}^{2}$ (island C). They were very close to each other and presented homogeneous soil properties [10]. The soil contained $13 \%$ clay, $10 \%$ silt, and $77 \%$ sand. The $\mathrm{pH}$ was 8.4 and the CEC was $19 \mathrm{cmol} \mathrm{kg}^{-1}$. The organic carbon content was $1.2 \%$ and the total nitrogen was $0.11 \%$. The soil was structurally poor, dense and difficult to penetrate for air, water, and roots [10]. A scarce and weak weed vegetation was present.

Management of the Study Site. In November, the traffic islands were glyphosate weeded. At the end of the same month, they were tilled to a depth of $10 \mathrm{~cm}$, then in half of the area, ("Compost Treated soil", CT hereafter), a sourceseparated municipal solid waste compost was incorporated into the soil at the rate of $3 \mathrm{~kg} / \mathrm{m}^{2}$, usually indicated for herbaceous and horticultural plants. The other half was left untreated ("No Compost Treated soil", NCT hereafter). The compost derived from a windrow-composting process with forced aeration, where temperature was higher than $60^{\circ} \mathrm{C}$. The compost complied with the Italian law n. 217/2006, also in terms of absence of pathogens and low heavy metal content, for its safe use as fertilizer. Some selected characteristics of the compost are showed in Table 1. A mixture of 25 herbaceous annuals was sown by hand broadcasting in the whole area at the rate of $5 \mathrm{~g} / \mathrm{m}^{2}$. The species were native and exotic, each of them flowering in a different period from early spring to late summer. The percentage of each species in the mixture was determined after a preliminary investigation on the germination capacity, the field assessment, and the morphological characteristics. The seeding was not irrigated and no irrigation was performed during the experimental period.

2.2. Analytical Determinations. Six soil composite samples (three subsamples) per treatment were taken in the 0$10 \mathrm{~cm}$ layer in December, February, May, and July. C content was determined with dry combustion by using a Leco CHN Analyzer. Bulk density was determined using the core method [11]. Wet sieving was used to determine the stability of soil aggregate in water. Air-dried aggregates (1$2 \mathrm{~mm}$ ) of soil were placed in $0.25 \mathrm{~mm}$ mesh sieves and moistened by the water rising by capillarity from a layer of wet sand, then immersed in deionized water and shaken at the rate of $60 \mathrm{rpm}$. A Water Stability Index (WSI) has been defined as: WSI $=100(1-A / B)$, where $A$ and $B$ are the weights of aggregates passing through the sieve after 5 and 60 minutes, respectively [12]. Measurements of porosity and pore size distribution in the range $0.002-$ $160 \mu \mathrm{m}$ were made with mercury intrusion porosimetry on undisturbed aggregates of about $2 \mathrm{~g}$ [13]. The volume of pores, measured as mercury intruded, was determined by means of the Washburn equation $p=-4 \gamma \cos \theta / d$, where $p$ is the pressure required to force the mercury into the pores of diameter $d, \gamma$ is the surface tension of the mercury ( 480 dyne/cm), and $\theta$ is the contact angle between the mercury and the soil surface $\left(140^{\circ}\right)$.

Every week, starting from the beginning of March, the quadrat method was used to detect and quantify the flowering of the species that had been sown. The number of flowering plants of each species was recorded in ten $1 \mathrm{~m}^{2}$ quadrats for each treatment.

2.3. Statistical Analysis. All results are the means of six measurements. Analysis of variance was performed to test the effect of time and treatments on the parameters investigated. The means were compared by using least significant differences calculated at $P<0.05$ (Newman-Keul's test).

\section{Results and Discussion}

3.1. Soil Characteristics. Levels and variations of organic C content in the two different areas and at different times are shown in Table 2. The two treatments had the same trend. Organic C content decreased in February, when the biological activities of the soil-plant system reached a minimum and did not produce new fresh organic matter, so that the catabolic processes affecting the organic matter became predominant. The organic $\mathrm{C}$ content raised in May, when the biological activities in the soil started again, due to the more favourable climatic conditions, and newly formed organic matter was present. In this picture, organic C content of CT was significantly greater than NCT on all sampling dates. In December, this was clearly due to the 
TABLE 2: Values of organic carbon content, bulk density, and water stability index (WSI) in no compost treated (NCT) and composttreated (CT) soil at different sampling dates.

\begin{tabular}{lcccc}
\hline & DEC & FEB & MAY & JUL \\
\hline Organic C\% & & & & \\
NCT & $1.36 \mathrm{aA}^{\dagger}$ & $0.81 \mathrm{bB}$ & $1.06 \mathrm{abA}$ & $1.18 \mathrm{abA}$ \\
CT & $2.07 \mathrm{aB}$ & $1.80 \mathrm{aA}$ & $2.80 \mathrm{bB}$ & $2.37 \mathrm{cB}$ \\
WSI & & & & \\
NCT & $2.9 \mathrm{aA}$ & $2.4 \mathrm{aA}$ & $3.4 \mathrm{aA}$ & $6.3 \mathrm{bA}$ \\
CT & $3.0 \mathrm{aA}$ & $3.0 \mathrm{aA}$ & $8.6 \mathrm{bB}$ & $15.1 \mathrm{cB}$ \\
Bulk density & & & & \\
NCT & $1.41 \mathrm{aA}$ & $1.50 \mathrm{aA}$ & $1.44 \mathrm{aA}$ & $1.42 \mathrm{aA}$ \\
CT & $1.46 \mathrm{aA}$ & $1.48 \mathrm{aA}$ & $1.30 \mathrm{bB}$ & $1.30 \mathrm{bB}$ \\
\hline
\end{tabular}

${ }^{\dagger}$ For each parameter values on the same row followed by the same lowercase letter are not significantly different; values on the same column followed by the same capital letter are not significantly different.

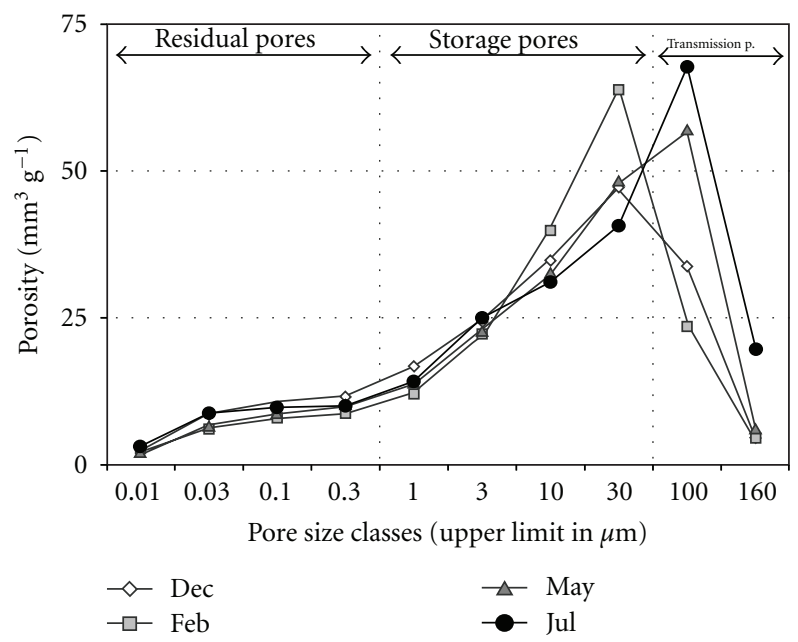

Figure 1: Pore size distribution of No compost-treated soil.

recent addition of the compost organic matter, whilst in February, May, and July there were at least two reasons. One is that the organic matter of the quality compost was stable and remained undecomposed for longer [3]. The other is that most of the organic $\mathrm{C}$ of the compost was protected by the soil structure at a level similar to that of the preexisting organic $\mathrm{C}$, as recently demonstrated by Sparvoli et al. [14]. The greater organic C content might have also stimulated a greater biological activity both in plants and microorganisms, unbalanced toward anabolic processes, which resulted in increased production of organic matter.

The influence of the newly incorporated organic $\mathrm{C}$ on the soil structure was investigated from two different points of view. (i) Water stability of aggregates, to evaluate if the added organic matter could prevent dispersion of soil particles, due to rainfall events or runoff or water action. (ii) Bulk density of the whole soil, plus porosity and pore size distribution of undisturbed aggregates, are used to evaluate the modifications of soil architecture and spatial arrangements of particles and aggregates.

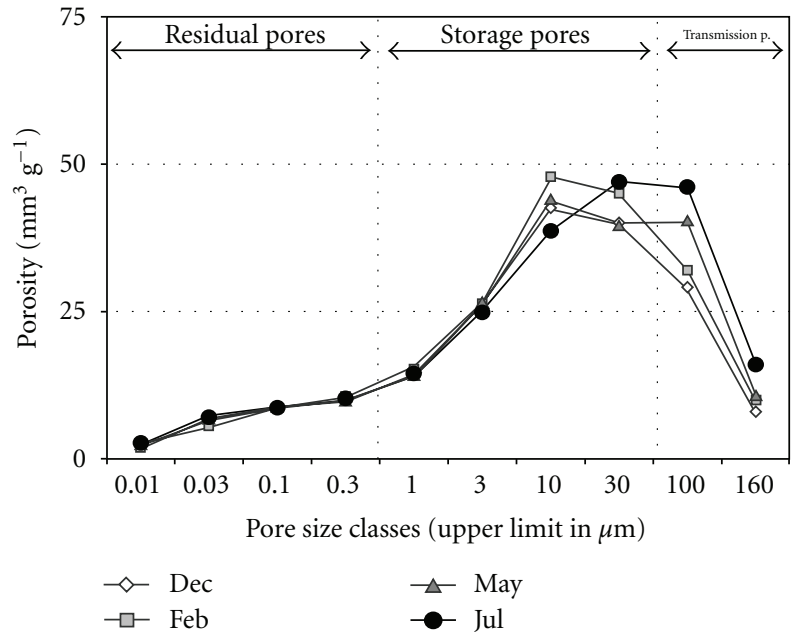

FIGURE 2: Pore size distribution of compost-treated soil.

TABLE 3: Values of transmission pores, storage pores and residual pores in no compost-treated (NCT) and compost-treated (CT) soil at different sampling dates (expressed as $\mathrm{mm}^{3} / \mathrm{g}$ ).

\begin{tabular}{lcccc}
\hline & DEC & FEB & MAY & JUL \\
\hline Transmission pores & & & & \\
$\quad$ NCT & $38 \mathrm{aA}^{\dagger}$ & $28 \mathrm{bA}$ & $83 \mathrm{cA}$ & $67 \mathrm{dA}$ \\
$\quad$ CT & $37 \mathrm{aA}$ & $42 \mathrm{aB}$ & $52 \mathrm{bB}$ & $62 \mathrm{cA}$ \\
Storage pores & & & & \\
$\quad$ NCT & $123 \mathrm{abA}$ & $137 \mathrm{bA}$ & $117 \mathrm{aA}$ & $111 \mathrm{aA}$ \\
$\quad$ CT & $123 \mathrm{aA}$ & $133 \mathrm{aA}$ & $124 \mathrm{aB}$ & $125 \mathrm{aB}$ \\
Residual pores & & & & \\
$\quad$ NCT & $32 \mathrm{aA}$ & $26 \mathrm{aA}$ & $28 \mathrm{aA}$ & $31 \mathrm{aA}$ \\
CT & $27 \mathrm{aA}$ & $27 \mathrm{aA}$ & $28 \mathrm{aA}$ & $28 \mathrm{aA}$ \\
\hline
\end{tabular}

${ }^{\dagger}$ For each parameter values on the same row followed by the same lowercase letter are not significantly different; values on the same column followed by the same capital letter are not significantly different.

Water stability is described in Table 2 by an index (WSI) that expresses the proportion of water stable aggregates greater than $250 \mu \mathrm{m}$. The WSI has been found to be very sensitive at measuring the effects of various organic C contents on soil structure of agricultural soils [15]. Moreover, the WSI changes during the growing season [16]. It usually reaches a maximum in late spring/early summer and then decreases to a minimum in winter. In NCT, the WSI of the soil ranged between 2.4 in February and 6.3 in July, always under the value of 10 , which indicates a very bad structural stability. The seasonal variations were smaller but consistent with those observed in agricultural soils [17]. This suggests a similar, though less effective, mechanism in this urban soil, where the strong interactions between the finer mineral constituents and the organic matter were limited by the sandy texture and the low-organic C content. The WSI of CT soil was similar to NCT in December and February, but sharply increased in May, almost trebling its previous values, and especially in July, indicating a little but significant 


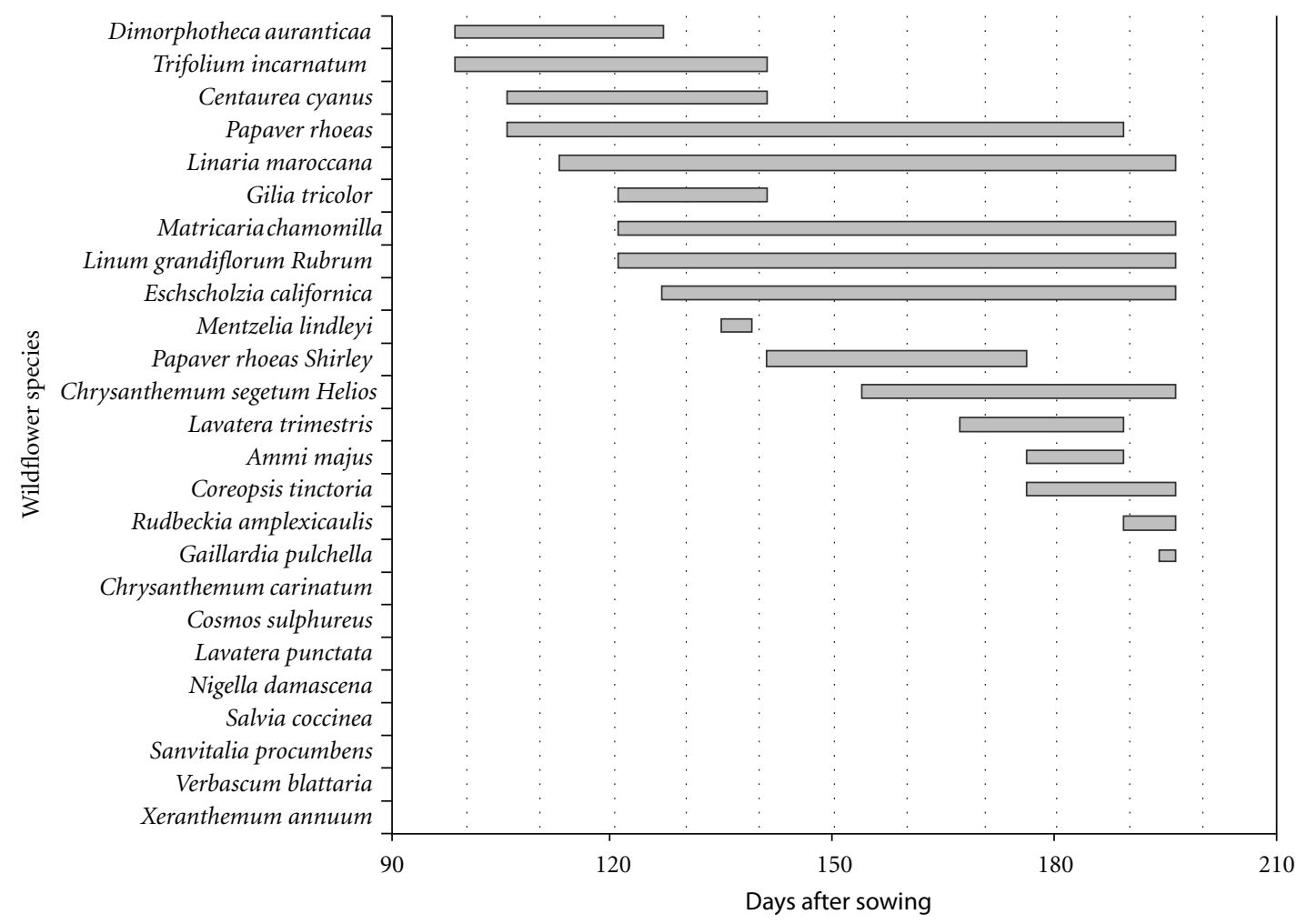

FIGURE 3: Flowering periods in no compost-treated soil.

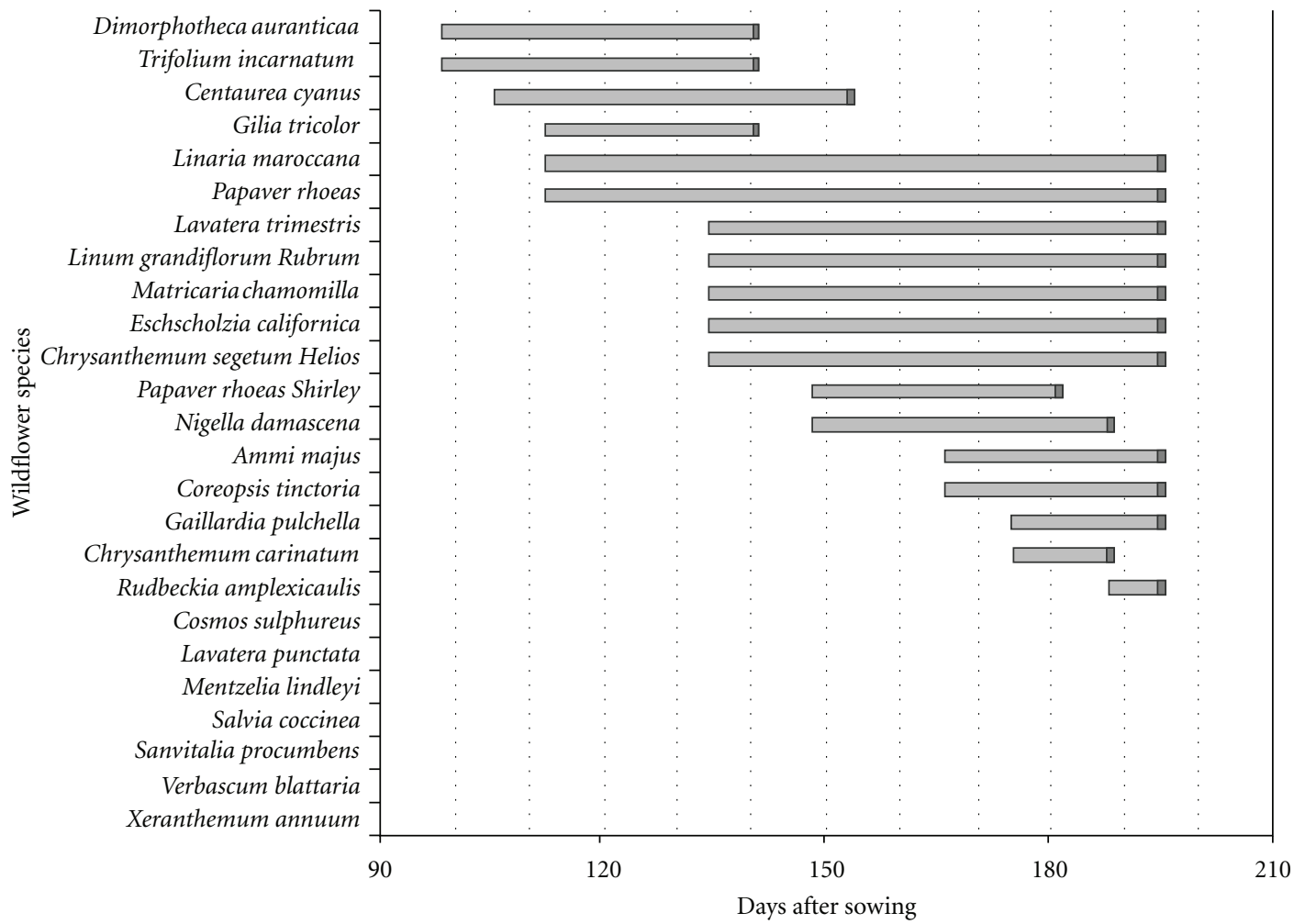

FIgURE 4: Flowering periods in compost-treated soil. 
increase in the formation of stable aggregates, which were resistant to the impact of water.

Bulk density of NCT showed similar values at all the sampling dates (Table 2). The minimum value was in December, probably due to the recent tillage, which produced a more open and unstable structure. The trend of CT bulk density was quite different. The value in February was the same as December and significantly higher than May and July. In this Compost-treated soil, there were no evidence of a collapse in the structural arrangement induced by the tillage. On the contrary, the proportion of the void space was maintained and gradually increased. Bulk density is a simple and useful parameter for evaluating soil structure, but it is still raw. A more effective description is given by pore size distribution, especially when pore classification reflects their function in the soil. In Figures 1 and 2, we used en expanded classification, where increasing values of pore diameter correspond to decreasing values of water tension (i.e., $1 \mu \mathrm{m}=\mathrm{pF} 3.5,3 \mu \mathrm{m}=\mathrm{pF} 3 ; 10 \mu \mathrm{m}=\mathrm{pF} 2.5$ ), which is preferable because it relates to the dominant water processes. Pore size classes were also grouped according to the Greenland's [18] terminology (Table 3), which describes transmission pores $(<50 \mu \mathrm{m})$, storage pores $(0.5-50 \mu \mathrm{m})$, and residual pores $(<0.5 \mu \mathrm{m})$ stressing their functional relevance. Transmission pores make air and water movement into the soil easier. Storage and residual pores are responsible for the storage of water and mineral nutrients, respectively.

Looking at the patterns in the two Figures and values in Table 3, two main considerations can be drawn. Firstly, NCT soil showed a larger variability among values of different sampling dates in every size class. There were clear maximums for each distribution curve and they were in different classes. On the other hand, in CT soil, the variability among the three sampling dates was much more narrow, higher values were distributed in more classes, and the maximum peak is in the same class $(3-10 \mu \mathrm{m})$. Secondly, storage pores remained quite constant and transmission pores increased constantly with time in CT, whilst in NCT the sharp increase of transmission pores was coupled with declining storage pores.

From a general examination of the overall pore size distribution data, it seems that compost-treated soil has acquired a more stable architecture of the void spaces, with a more balanced distribution in the different size classes, with a tendency to increase pores that retain water or let it flow in the bulk soil.

3.2. Plant Growth. The wildflower mixture used in this work has been chosen for practical and aesthetical reasons. It should ensure an early and lasting cover of the seeded area, grow to a height that does not disturb drivers, and offer a pleasant array of flowers and colours. Thus, the duration and the quantity of flowering are the main parameters discussed here. The duration of flowering of the single species until June is shown in Figures 3 and 4. Although the quality of the floristic composition was the same in the two areas, they differed in terms of flowering in three of the species: Mendzelia lindley was present only in NCT, Nigella

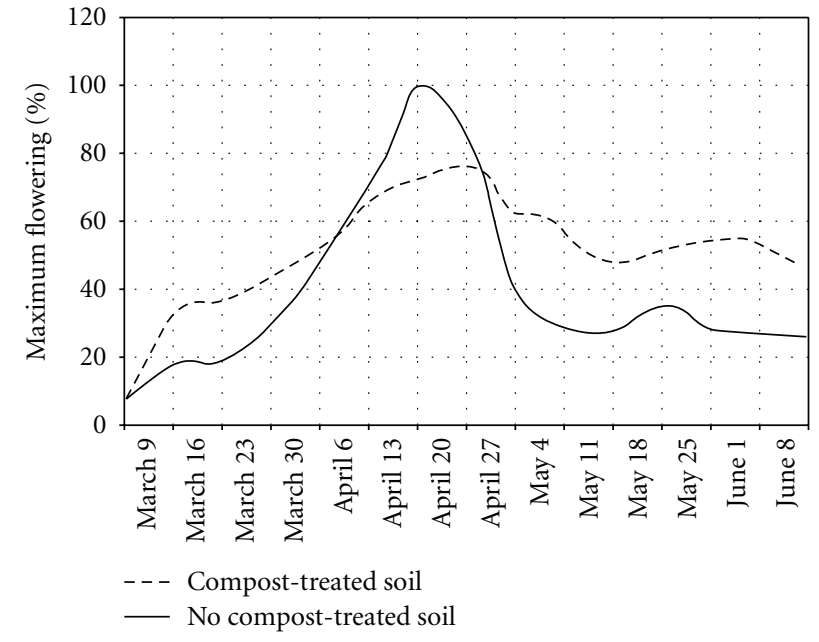

FIGURE 5: Flowering intensity expressed as percent of maximum flowering, recorded in NCT soil on April 20.

damascena, and Chrisanthemum carinatum flowered only in CT. As a total number, there were 18 flowered species in CT, while there were 17 in NCT. The mean duration of flowering of the single species was 39 days in NCT and 45 days in CT. Only five species had a longer blooming in the NCT soil. Among these, Papaver rhoeas and Matricaria Camomilla often behave like ruderals, dominating the planting and so decreasing the growth of the others, which reduces the ornamental effect. In this case, in fact, the quantitative data of each species (not shown) confirmed that these two species had a high blooming peak. Moreover, when they decreased, the other species were not able to develop satisfactorily. It can be argued that the beneficial effects of the compost treatment contrasted and reduced the ruderal behaviour of some species. In Figure 5, the overall quantity of flowering is presented. Data are expressed as a percentage of the maximum flowering, which had been recorded in NCT soil on April 20. The duration of the flowering was the same in the two areas, but NCT showed a very high peak and then a rapid decrease, whilst CT showed a higher quantity of flowers for a longer period. To conclude, the planting in the CT soil was richer in terms of individuals and longer in time, compared with the NCT soil.

\section{Conclusions}

Seven month after the treatment, the compost-treated soil showed better soil physical parameters, in terms of less compaction and presence of pores that retain water or let it flow in the bulk soil. These characteristics were more constant over time, due to the increased structural stability of the aggregates. The enhanced physical quality of the soil, when treated with compost, reflected better conditions for growth and for development of the wildflowers, which produced a higher quantity of flowers for a longer time. The combined use of compost and wildflowers can be considered a good practice for the management of poor quality derelict urban soils. 


\section{Acknowledgments}

The work was carried out within research activities in the frame of the project "wildflowers plantings for the sustainable management of urban green areas", funded by ARSIA, Regione Toscana. Authors wish to thank the Parks and Gardens Office of the Municipality of Livorno for the management of the experimental area and Toscana Ricicla Consortium for the compost supply.

\section{References}

[1] P. Bullock and P. J. Gregory, Soils in the Urban Environment, Blackwell Scientific Publications, Oxford, UK, 1991.

[2] C. G. Cogger, "Potential compost benefits for restoration of soils disturbed by urban development," Compost Science and Utilization, vol. 13, no. 4, pp. 243-251, 2005.

[3] A. Sæbø and F. Ferrini, "The use of compost in urban green areas-a review for practical application," Urban Forestry and Urban Greening, vol. 4, no. 3-4, pp. 159-169, 2006.

[4] F. Bretzel and M. Calderisi, "Metal contamination in urban soils of coastal Tuscany," Environmental Monitoring and Assessment, vol. 118, no. 1-3, pp. 319-335, 2006.

[5] J. W. Singer, R. W. Malone, M. D. Tomer, T. G. Meade, and J. Welch, "Compost effect on water retention and native plant establishment on a construction embankment," Journal of Soil and Water Conservation, vol. 61, no. 5, pp. 268-272, 2006.

[6] P. Andrés, V. Zapater, and M. Pamplona, "Stabilization of motorway slopes with herbaceous cover Catalonia, Spain," Restoration Ecology, vol. 4, no. 1, pp. 51-60, 1996.

[7] F. Bretzel, B. Pezzarossa, F. Malorgio, and C. Carrai, "Specie erbacee spontanee (wildflowers) per la riqualificazione ambientale di suoli marginali," Flortecnica, vol. 292, pp. 2-8, 2006.

[8] F. Bretzel, B. Pezzarossa, S. Benvenuti, A. Bravi, and F. Malorgio, "Soil influence on the performance of 26 native herbaceous plants suitable for sustainable Mediterranean landscaping," Acta Oecologica, vol. 35, no. 5, pp. 657-663, 2009.

[9] F. Bretzel and D. J. Hitchmough, in Proceedings of the 1st International Conference on Soils of Urban, Industrial, Traffic and Mining Areas, pp. 511-515, Essen, Germany, 2000.

[10] F. Bretzel, B. Pezzarossa, R. Pini, and G. Vigna Guidi, "Sustainable management of traffic islands. An experience in Italy," in Proceedings of the 2nd International Conference on Soils of Urban, Industrial, Traffic and Mining Areas, pp. 259-260, Nancy, France, 2003.

[11] G. R. Blake and K. H. Hartge, "Bulk density," in Methods of Soil Analysis. Part 1. Physical and Mineralogical Methods, A. Klute, Ed., pp. 363-375, ASA-SSSA, Madison, Wis, USA, 2nd edition, 1986.

[12] G. Vigna Guidi, R. Pini, G. Poggio, and G. Petruzzelli, "Changes of soil structure in two compost amended Italian soils," Agricoltura Mediterranea, vol. 119, pp. 322-326, 1989.

[13] G. Guidi, R. Pini, and G. Poggio, "Porosity in a puddled rice soil as measured with mercury-intrusion porosimetry," Soil Science, vol. 145, no. 6, pp. 455-460, 1988.

[14] E. Sparvoli, R. Pini, L. D’Acqui, and M. Scatena, "Quality compost and soil quality," in Geophysical Research Abstracts, vol. 10, EGU General Assembly, Vienna, Austria, 2008.

[15] G. Guidi, R. Pini, and G. Poggio, "Effect of compost on some soil physical properties: results of four year experiments," in Proceedings of the 2nd International Conference on Environmental Protection, vol. 4.B, pp. 67-73, Ischia, Italy, 1988.
[16] G. Guidi, A. Pera, M. Giovannetti, G. Poggio, and M. de Bertoldi, "Variations of soil structure and microbial population in a compost amended soil," Plant and Soil, vol. 106, no. 1, pp. 113-119, 1988.

[17] G. Guidi, R. Pini, and G. Poggio, "Modifications of some physical properties in two compost amended Italian soils," in Sewage Sludge Treatment and Use: New Developments, Technological Aspects and Environmental Effects, A. H. Dirkzwager, Ed., Elsevier Science, London, UK, 1989.

[18] D. J. Greenland, "Soil damage by intensive arable cultivation: temporary or transient?" Philosophical Transactions of the Royal Society, vol. 281, pp. 193-208, 1977. 

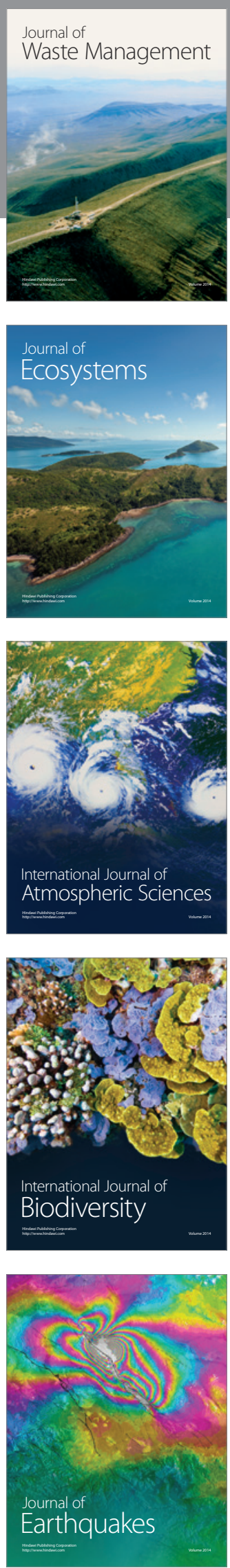
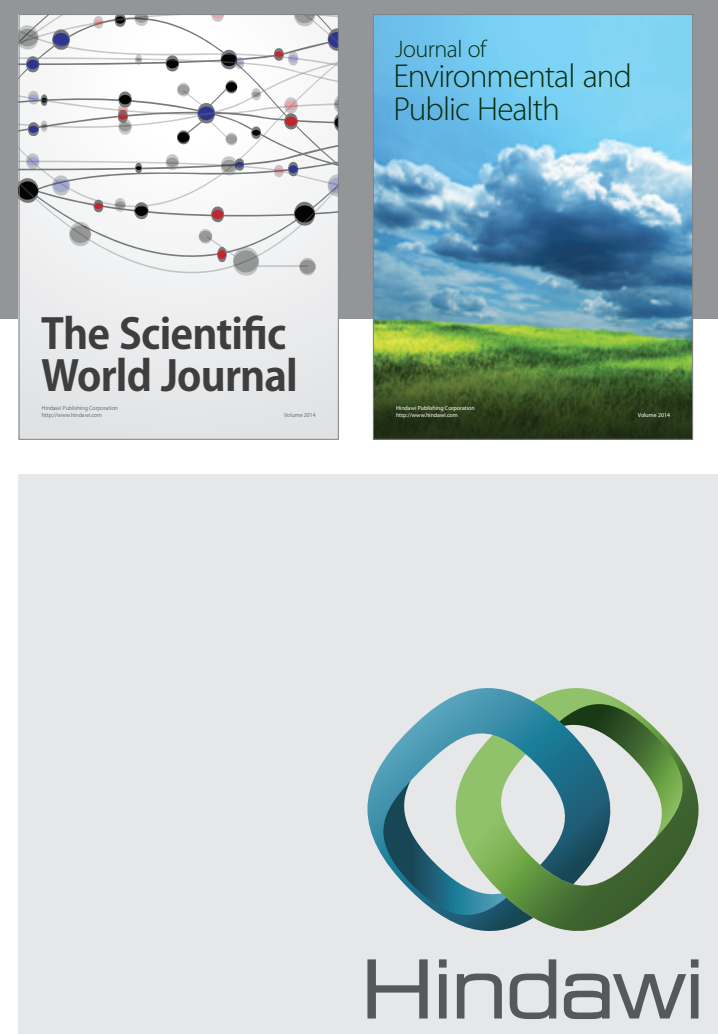

Submit your manuscripts at

http://www.hindawi.com
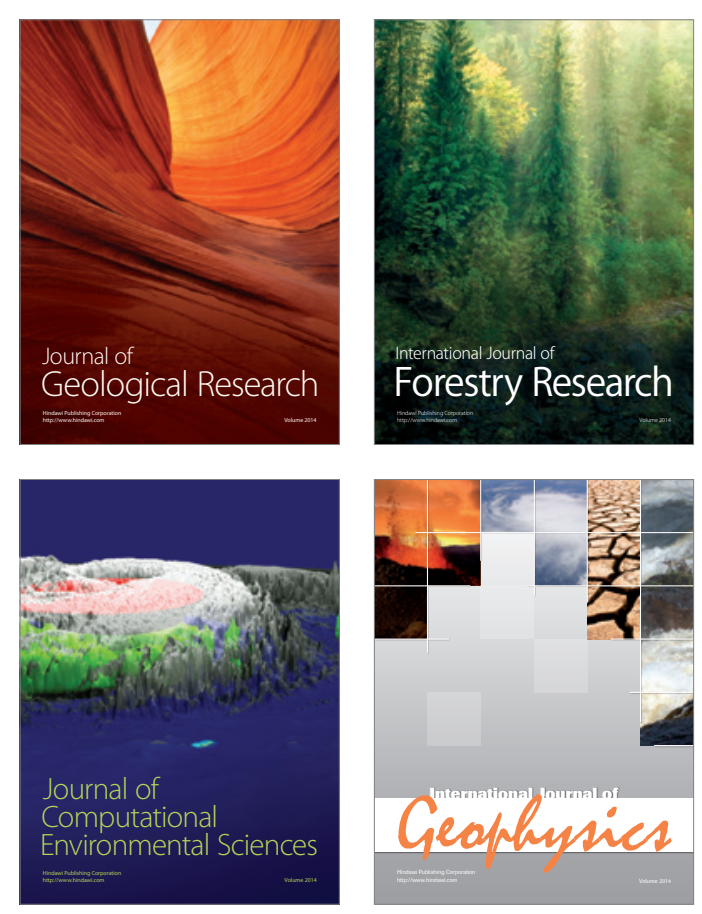
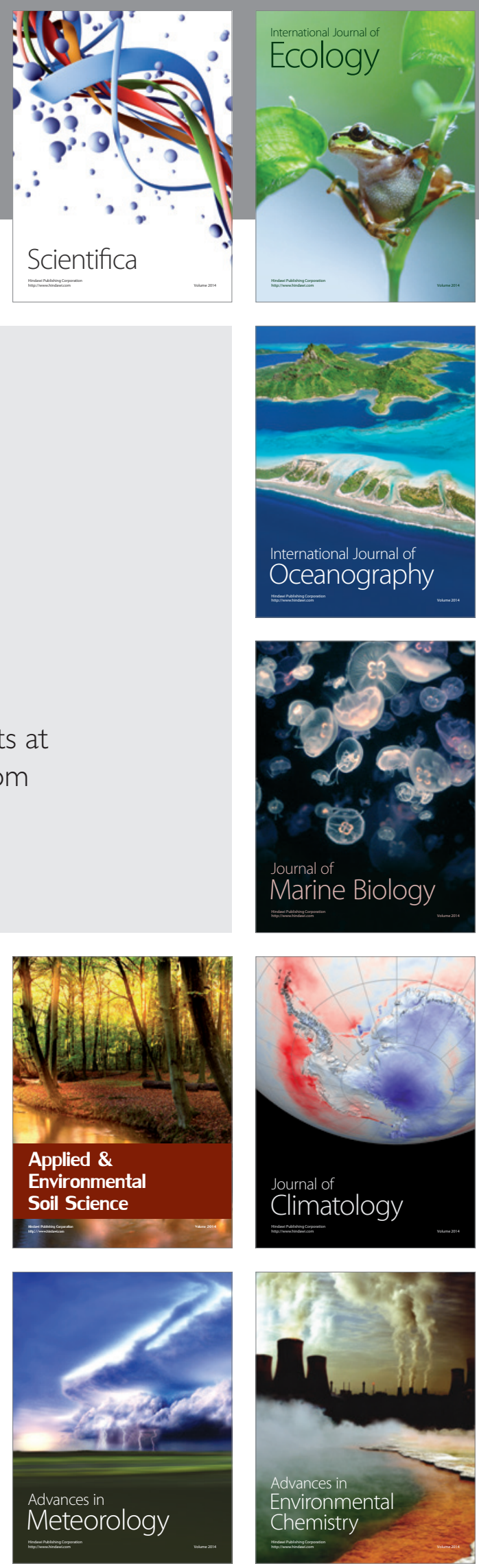